\title{
Segmentation of the buffalo meat consumer market in Belém, Pará, Brazil
}

\section{Cristiane Soares Simon Marques ${ }^{1}$, Ricardo Pedroso Oaigen ${ }^{2}$, Carina Martins de Moraes ${ }^{3}$, Marcos Antônio Souza dos Santos ${ }^{4}$, José de Brito Lourenço Júnior ${ }^{1}$, Isis Abel ${ }^{3}$}

\author{
1 Universidade Federal do Pará, Programa de Pós-graduação em Ciência Animal, Belém, PA, Brazil. \\ ${ }^{2}$ Universidade Federal do Pampa, Uruguaiana, RS, Brazil. \\ ${ }^{3}$ Universidade Federal do Pará, Programa de Pós-graduação em Saúde Animal na Amazônia, Castanhal, PA, Brazil. \\ ${ }^{4}$ Universidade Federal Rural da Amazonas, Instituto Socioambiental e dos Recursos Hídricos, Belém, PA, Brazil.
}

\begin{abstract}
The objective of this study was to identify different market segments for buffalo meat with target groups defined in the city of Belém, Pará, Brazil. Paired samples of beef and buffalo meat were given to 447 volunteers, and a sensory analysis of the products was conducted. After the tasting, a questionnaire was administered to obtain demographic (age, educational level, marital status) and economic (household income) data as well as information on the habits of respondents and preferences regarding buffalo meat. The factors were estimated using the principal components method and the factors with characteristic roots greater than one were extracted. To check the suitability of the factorial model, Bartlett's sphericity test and the Kaiser-Meyer-Olkin (KMO) test were used. A factor analysis was performed, identifying five factors with common variability dimensions. The study has helped identify four distinct market segments which, combined with a targeted marketing strategy, can be used to leverage the productive chain: I - Young and interested, II - Mixed and indifferent, III - Graduates and successful, and IV - Healthy women. All had positive responses to buffalo meat; clusters I and III stood out with regard to several indicators, especially those related to the preference for buffalo meat and the predisposition to purchase and include it in meals. The sensory analysis indicated that consumers showed a greater acceptance of buffalo meat based on the characteristics of flavour, colour, succulence and tenderness. The study helps to identify market segments with distinct features that, combined with a targeted marketing strategy, can be used to leverage the supply chain
\end{abstract}

Key Words: buffalo meat, cluster analysis, consumers

\section{Introduction}

Buffalo farming is a traditional activity in the state of Pará, which currently contains approximately $36 \%$ of the total buffalo population in Brazil, representing the largest herd in the country. The main purpose of this activity is the production of meat, which is becoming an important alternative source of animal protein for the population (Bernardes, 2007).

Buffalo meat has excellent sensory quality and acknowledged nutritional and functional characteristics. However, failure to identify the potential uses of this product has limited the ability of farmers to transform these advantages into greater profitability; in some regions, this contributes to a slower pace of expansion of this activity despite the existing market potential (Silva and Nardi Junior, 2014).

Received October 16, 2015 and accepted March 28, 2016.

Corresponding author: cristianevet2011@gmail.com

http://dx.doi.org/10.1590/S1806-92902016000600008

Copyright (c) 2016 Sociedade Brasileira de Zootecnia. This is an Open Access article distributed under the terms of the Creative Commons Attribution License (http://creativecommons.org/licenses/by/4.0/), which permits unrestricted use, distribution, and reproduction in any medium, provided the original work is properly cited.
The development of this activity has also been hampered by information asymmetries among the links that make up the production chain because statistics on buffalo meat consumption are scarce and usually consolidated with data on beef (Bernardes, 2007).

According to Bernués et al. (2012) and Trienekens et al. (2012), understanding consumer behaviour has become an important strategic consideration. Knowledge about what consumers want and their opinions about a product and the subsequent dissemination of this information along the chain represents a competitive advantage for agribusiness systems because it allows for production coordination and the ability to offer retail consumers exactly what they expect. Market segmentation is a tool used to study the differences among consumers to stratify the market into meaningful homogeneous groups (segments or niches). Marketing analyses currently combine many variables in an attempt to identify the target groups that are most representative of consumers. Thus, market segmentation is essential for marketing policies, guiding the choice of welldefined segments to design competitive strategies (Bernués et al., 2012; Onwezen et al., 2012).

The objective of the study was to identify different market segments for buffalo meat, with target groups 
defined starting the characteristics of consumers and potential consumers in the city of Belem, state of Pará, Brazil.

\section{Material and Methods}

This study was previously submitted to and approved by the Ethics Committee of Universidade Federal do Pará, according to Resolution No. 196/96 of the National Health Council (Conselho Nacional de Saúde), through the Ethics Committee for Research with Humans. The study was certified under CAAE protocol no. 12593313.4.0000.0018 and review no. 354.570 .

An exploratory and descriptive survey was conducted (Hill and Hill, 2012; Malhotra, 2012) in Belém, Pará, in the Brazilian Amazon. Sensory analysis was conducted, followed by interviews with randomly selected individuals, including consumers and non-consumers of buffalo meat. The tests were conducted in four different districts of the city, at supermarket entrances. Supermarkets were chosen because, as described by Behrens et al. (2010), they are the places where red meat is most frequently purchased.

To ensure sample representativeness and distribution homogeneity, the sample size was defined by estimating proportions of the population with a sample degree of confidence of $95 \%(Z=$ standard deviation of 1.96$)$ and a margin of error of $5 \%$, according to equation $n=\left(Z^{2}{ }_{\alpha 2} \cdot p \cdot q\right) / E^{2}$, in which $Z^{2}{ }_{\alpha / 2}$ is the desired degree of confidence, $\mathrm{p}$ is the proportion of the population belonging to the category under study, $\mathrm{q}$ is the proportion of the population not belonging to the category of interest in the study $(q=1-p), n$ is the number of individuals in the sample, and $\mathrm{E}$ is the margin of error or maximum estimation error (Malhotra, 2012).

Based on the current population of the city of Belém, Pará, the calculation of the sample size showed that the minimum number of samples to be collected should be 383 questionnaires. A total of 447 questionnaires were administered to ensure the necessary safety margin for the taste tests. The sample included both consumers of buffalo meat and potential consumers (people who do not yet consume this product).

The affective sensory method was used to obtain data relating to the acceptance of buffalo meat based on a paired comparison test between beef and buffalo (Minin, 2012). The following meat cuts were used: lower round, sirloin, and tenderloin, all of which were acquired at a slaughterhouse licensed by the Brazilian Federal Inspection Service (Serviço de Inspeção Federal do Brasil - SIF). The slaughtered animals (cattle and buffalo) were approximately 25 months old, as measured by the Animal
Transit Guide (Guia de Trânsito Animal - GTA) and the dental records of the animals, which were raised in similar production systems, with access to Brachiaria brizantha and Panicum maximum pastures. Half of the carcasses were kept in chambers refrigerated to approximately $5^{\circ} \mathrm{C}$ for $24 \mathrm{~h}$; after boning, the sample cuts were stored at approximately $-12{ }^{\circ} \mathrm{C}$ (Jo et al., 2014; Lee et al., 2015).

The meat cuts were required to obtain a negative result in a microbiological test for Salmonella prior to the start of the activities. The cuts were thawed $24 \mathrm{~h}$ prior to the planned test administration date. For the tastings, the sections were portioned into pieces approximately $0.6 \mathrm{~cm}$ in height and weighing $25 \mathrm{~g}$ and seasoned with salt at a ratio of $10 \mathrm{~g} / \mathrm{kg}$. These samples were then cooked at $230{ }^{\circ} \mathrm{C}$ for seven minutes ( $3.5 \mathrm{~min}$ for each side) on two independent electrical grills, one for each type of meat. This equipment had a thermostat for temperature control.

The sensory analysis was conducted in the second half of 2013 , from 9.00 to $11.00 \mathrm{~h}$ and 14.00 to $17.00 \mathrm{~h}$. The two samples were randomly offered to consumers and identified using only three non-sequential numbers: 254 for buffalo and 681 for beef. Participants were given a glass of water to drink in the interval between the first and second tastings (Minin, 2012).

After the tasting, the respondent answered a questionnaire about their perceptions of the sensory attributes of flavour, colour, tenderness, and succulence, as well as their willingness to purchase the evaluated meats (Hill and Hill, 2012; Minin, 2012). Consumers had not been previously trained. For this reason, the questionnaire was designed with a five-point Hedonic scale for each attribute (1 - Liked a lot; 2 - Liked moderately; 3 - Neither liked nor disliked; 4 - Disliked moderately; and 5 - Disliked a lot). At the end of each tasting, a questionnaire was administered to evaluate purchase intention using five options ( 1 - Would certainly buy; 2 - Would possibly buy; 3 - May or may not buy; 4 - Possibly would not buy; and 5 - Certainly would not buy).

The questionnaire had a semi-structured format and was prepared through literature reviews and preliminary studies of the production chain, potential consumers, and relevant information covered in interviews with buffalo farming experts. Information regarding the distribution of the buffalo herd in the cities of Pará State, elements concerning the divergence of prices between the chain links (Producer/Industry/Retail), research on various aspects that could influence the consumption of buffalo meat, and other issues involving the production chain were addressed in the preliminary research study (Hair Jr. et al., 2007; Malhotra, 2012). The profiles of the respondents were evaluated 
based on gender, age, household income, educational level, marital status, and smoking status. The remaining questions were directed to individuals with and without the habit of consuming buffalo meat (consumers and potential consumers) and covered the following aspects: a) behaviour of buffalo meat consumers and potential consumers with regard to their consumption preferences and habits; b) cultural and social characteristics; c) demographic factors and their influence on consumption; and d) knowledge of, appreciation of, and factors limiting buffalo meat consumption.

The questions were objective and multiple-choice, with some being semi-open (Hill and Hill, 2012). A pre-test was conducted with students at Universidade Federal do Pará, in Castanhal, state of Pará, to check the understanding of the questionnaire.

Data were analysed using two multivariate analysis techniques. Initially, factor analysis was conducted to identify common dimensions of variability between variables. This technique assumes that correlations between variables arise because they are related to the same factor. The objective is to identify factors that are not directly observable based on the correlation between a set of variables that are observable and subject to measurement (Malhotra, 2012).

The factors were estimated using the principal components method and the factors with characteristic roots greater than one were extracted. To check the suitability of the factorial model, Bartlett's sphericity test and the KaiserMeyer-Olkin (KMO) test were used. The former tests the hypothesis that the correlation matrix is an identity matrix, i.e., its determinant is equal to one and all other values are zero (this means that there is no correlation between the variables). The latter evaluates the input value of the variables in the model, which can vary between zero and one (Johnson and Wichern, 2007).

Cluster analysis was also used to classify objects or cases into relatively homogeneous groups, with the objects in each cluster being similar to each other but different to the objects in the other clusters (Malhotra, 2012). To define the clusters, we used the scores obtained in the factor analysis, using the Ward method based on the square of the Euclidean distance. All statistical procedures were performed on IBM SPSS ${ }^{\odot}$ version 20.0.

\section{Results and Discussion}

The use of factor analysis enabled the estimation of five factors with characteristic roots greater than one, which explained $60.77 \%$ of the total variance of the data. Bartlett's test was significant at $1 \%$, rejecting the null hypothesis that the correlation matrix is an identity matrix. The KMO test showed a value of 0.760 , indicating that the sample data are suitable for factor analysis (Table 1) (F1: Sensory association of buffalo meat; F2: Educational level and household income; F3: Access to information, origin, and quality control of meat; F4: Nutritional value and colour of the meat and fat; and F5: Gender and age).

Factor 1, sensory association of buffalo meat, explained the greatest portion of the total variance $(22.75 \%)$ and is positively associated with the variables related to consumer

Table 1 - Factor loadings after orthogonal rotation and corresponding commonalities

\begin{tabular}{|c|c|c|c|c|c|c|}
\hline \multirow{2}{*}{ Variable } & \multicolumn{5}{|c|}{ Factor } & \multirow{2}{*}{ Commonality $^{1}$} \\
\hline & $\mathrm{F} 1$ & $\mathrm{~F} 2$ & F3 & F4 & F5 & \\
\hline Evaluation of buffalo meat flavour & 0.8322 & -0.0787 & -0.0497 & 0.0825 & -0.0056 & 0.7080 \\
\hline Evaluation of buffalo meat colour & 0.6700 & 0.0591 & 0.1172 & 0.0755 & -0.2470 & 0.5329 \\
\hline Evaluation of buffalo meat succulence & 0.8498 & 0.0837 & 0.0359 & -0.0687 & 0.0090 & 0.7352 \\
\hline Evaluation of buffalo meat tenderness & 0.7316 & 0.0670 & -0.0623 & -0.0871 & 0.2226 & 0.6007 \\
\hline Intention to purchase buffalo meat & 0.8642 & 0.0153 & -0.0013 & 0.0503 & -0.0222 & 0.7501 \\
\hline Educational level & 0.0664 & 0.8094 & -0.0641 & -0.0724 & -0.0898 & 0.6770 \\
\hline Household income & 0.0260 & 0.8492 & -0.0279 & 0.0653 & 0.1016 & 0.7371 \\
\hline $\begin{array}{l}\text { Having access to information regarding buffalo meat may improve } \\
\text { sales of the product }\end{array}$ & 0.1410 & 0.0344 & 0.3508 & 0.3400 & -0.1523 & 0.2829 \\
\hline Would you pay extra for buffalo meat with a certified origin? & 0.0296 & -0.0538 & 0.7238 & -0.0326 & -0.0851 & 0.5360 \\
\hline Do you think it is important for buffalo meat to have the SIF seal? & -0.0699 & -0.0813 & 0.6649 & 0.1005 & 0.2868 & 0.5460 \\
\hline Nutritional value & -0.0600 & -0.2173 & 0.2119 & 0.6936 & -0.0132 & 0.5771 \\
\hline Colour of meat and fat & -0.0299 & -0.1785 & 0.1575 & -0.7961 & -0.1401 & 0.7110 \\
\hline Gender & 0.0553 & -0.2358 & -0.3205 & 0.0222 & 0.5181 & 0.4304 \\
\hline Age & -0.0358 & 0.1822 & 0.2573 & 0.0465 & 0.7624 & 0.6841 \\
\hline Variance $(\%)$ & 22.751 & 11.259 & 9.671 & 9.151 & 7.941 & - \\
\hline Cumulative variance (\%) & 22.751 & 34.010 & 43.681 & 52.832 & $60.773^{1}$ & - \\
\hline
\end{tabular}

Factors with the greatest loadings per variable are in bold.

Bartlett's sphericity test $=1,277.866(\mathrm{P}<0.01)$ and $\mathrm{KMO}=0.760$

F1 - sensory association of buffalo meat; F2 - educational level and household income; F3 - access to information, origin and quality control of meat; F4 - nutritional value and colour of the meat and fat; F5 - gender and age; SIF - Brazilian Federal Inspection Service.

${ }^{1}$ Proportion of the total variation of the variable explained by common factors. 
satisfaction with meat attributes, such as $X_{1}$ (assessment of flavour), $\mathrm{X}_{2}$ (assessment of colour), $\mathrm{X}_{3}$ (assessment of succulence), $\mathrm{X}_{4}$ (assessment of tenderness), and $X_{5}$ (intention to purchase buffalo meat). According to Iannario et al. (2012), sensory analysis of food products is important because it provides fundamental guidelines for their production and marketing with regard to consumer preferences and demands.

The association of these variables with a single factor is justified by the fact that they are perceptible and fundamental characteristics in determining the sensory quality of food (Banovic et al., 2009; Verbeke et al., 2010). The outcome of the sensory analysis based on the Hedonic Scale showed that most consumers chose "Liked a lot" for buffalo meat and "Liked moderately" for beef; however, there was no central tendency among opinions, which is indicative of the potential to include buffalo meat in the market as a substitute for beef (Table 2).

The second factor, educational level and household income, accounted for $11.25 \%$ of the total variance and is related to the variables $\mathrm{X}_{6}$ (educational level) and $\mathrm{X}_{7}$ (household income). Educational level and household income are important demographic characteristics that affect the acquisition and acceptance of foods (Banovic et al., 2012). Banovic et al. (2012) observed that as the educational levels of consumers increase, the frequency of beef consumption decreases significantly. In turn, Brisola and Castro (2005) found that consumer demands increase with educational level because better-educated consumers select their preferred cuts and purchasing locations and are generally predisposed to pay more for the products they purchase.

The third factor, access to information on the origin and quality control of meat, explained $9.67 \%$ of the total variance. This factor is positively related to the following variables: $\mathrm{X}_{8}$ (access to information about buffalo meat

Table 2 - Satisfaction scale regarding attributes of beef and buffalo meat $(\%)$

\begin{tabular}{llcccc}
\hline Meat & Satisfaction scale & Flavour & Colour & Succulence & Tenderness \\
\hline Buffalo & Liked a lot & 53.2 & 54.4 & 55.0 & 68.2 \\
& Liked moderately & 35.8 & 34.7 & 30.2 & 19.7 \\
& Neither liked nor & 4.3 & 6.0 & 5.8 & 2.5 \\
& disliked & & & & \\
& Disliked moderately & 4.7 & 3.8 & 5.6 & 5.6 \\
& Disliked a lot & 2.0 & 1.1 & 3.4 & 4.0 \\
\multirow{5}{*}{ Beef } & Liked a lot & 47.9 & 50.6 & 43.4 & 33.8 \\
& Liked moderately & 41.2 & 36.9 & 34.0 & 36.9 \\
& Neither liked nor & 3.8 & 6.7 & 8.5 & 6.5 \\
& disliked & & & & \\
& Disliked moderately & 4.5 & 2.9 & 9.2 & 15.0 \\
& Disliked a lot & 2.7 & 2.9 & 4.9 & 7.8 \\
\hline
\end{tabular}

may favour the purchase of this product), $\mathrm{X}_{9}$ (willingness to pay more for buffalo meat with a certified origin), and $\mathrm{X}_{10}$ (consider it important for buffalo meat to have the SIF seal). These factors indicate the importance of information in purchase-related decision making because consumers often seek information stored in their memories as well as from the external environment (Rutsaert et al., 2005). According to McGloin et al. (2009), communication related to food must be clear and easy to understand to produce better results.

With regard to product certification, the data support the statements of Brandão et al. (2012) in their study on increased demand for products with certified geographical origins. According to these authors, consumers consider the geographical origin of meat to be an indicator of quality and are willing to pay more for meat possessing this differentiation. In addition to perceived quality, consumers believe that this type of certification confers greater security and confidence to the product.

The fourth factor, nutritional value and colour of the meat and fat, explained $9.15 \%$ of the total variance, relating to the variables $\mathrm{X}_{11}$ (nutritional value) and $\mathrm{X}_{12}$ (colour of the meat and fat). Consumer interest in issues related to health has increased in recent years, and demand for better quality of life, balanced diets and dieting have created a demand for foods that are lower in calories and more nutritious (Minin, 2012).

Buffalo meat fits this profile due to its nutritional and functional properties and its low total and marbled fat content, high content of hypocholesterolaemic fatty acids (fatty acids that help remove "bad", LDL cholesterol from the bloodstream), lower atherogenicity and thrombogenicity (fats that are not deposited in the blood vessels), high content of omega-3/omega-6, higher protein content, and lower calorie content than other types of meat such as poultry, sheep, and zebu or taurine cattle (Lira et al., 2005; Giordano et al., 2010). Colours are visual elements that have the ability to stimulate consumer perceptions, emotions and attitudes when choosing meat; brighter colours are usually related to higher quality or fresher products (Banovic et al., 2012).

Regarding household income, Pinheiro et al. (2011) found that individuals with higher incomes consume leaner meats and in reduced amounts. This behaviour may favour the consumption of buffalo meat due to its nutritional properties and reduced amount of fat. The fifth factor, gender and age, explained $7.94 \%$ of the total variance, relating positively to the variables $\mathrm{X}_{13}$ (gender) and $\mathrm{X}_{14}$ (age). These variables are non-sensorial demographic characteristics linked to consumers that naturally exhibit different behaviours in the face of everyday situations. This 
information is important for use in market segmentation as the selection criteria of consumers are often different between specific age range (Minin, 2012).

A cluster analysis was performed based on the scores of the five previously described factors. This analysis divided the sample into four groups of consumers (Tables $3,4,5,6$, and 7). The main variables used to differentiate among the groups were age, educational level, income, predisposition to consume buffalo meat, and purchase intention. According to Bernués et al. (2012) and Trienekens et al. (2012), establishing a differentiation strategy is essential for businesses to attract customers; segmentation facilitates an understanding of the market; and product positioning studies and consumer analysis assist in the making of pricing decisions and the effectiveness of the communication process.

Group I, Young and interested, was the largest group, with a total of 181 individuals (40\% of the sample). This group liked buffalo meat and was also more predisposed to buy it. It is characterised by young people between the ages of 25 and 45; they predominantly have secondary/technical education and the lowest salary range, ranging between one and four times the minimum wage. Most group members are unaware of the benefits of buffalo meat relative to the other groups; however, all stated that having access to information about the benefits of this food product may favour purchase, and they are willing to pay a higher price for meat with a certified origin and the SIF seal. According to Schnettler et al. (2009) and Banovic et al. (2012), the higher value that a consumer is willing to pay for certified meat is considered important, which shows that some consumer groups can be reached by guaranteeing quality demands.

Consumers of buffalo meat (14.4\%) stood out within the group for exhibiting consumption habits that are more connected to family and friends; however, they consume this product less frequently (monthly or annually). For potential consumers $(85.6 \%)$, the rationale for not consuming buffalo meat was product unavailability at the point of sale and lack of knowledge about its benefits; however, 97.3\% are willing to include it in their diets.

The availability of buffalo meat in retail outlets is influenced by many factors, including the lack of joint effort between those involved in the production chain, placement in the market, ignorance of the consumer market, and possible fraud involving changing the label on the product to indicate that it is beef due to the similarity of the two

Table 3 - Demographic data and household income of interviewees (\%)

\begin{tabular}{|c|c|c|c|c|c|}
\hline \multirow{2}{*}{ Variable } & & \multicolumn{4}{|c|}{ Cluster } \\
\hline & & $\mathrm{I}(\mathrm{n}=181)$ & II $(\mathrm{n}=51)$ & III $(\mathrm{n}=153)$ & $\operatorname{IV}(\mathrm{n}=62)$ \\
\hline \multirow[t]{2}{*}{ Gender } & Male & 50.3 & 58.8 & 54.9 & 38.7 \\
\hline & Female & 49.7 & 41.2 & 45.1 & 61.3 \\
\hline \multirow[t]{4}{*}{ Age class (year) } & Less than 25 & 17.1 & 19.6 & 3.9 & 9.7 \\
\hline & 25 to 34 & 29.8 & 17.6 & 21.6 & 25.8 \\
\hline & 35 to 44 & 26.5 & 15.7 & 23.5 & 24.2 \\
\hline & 65 and over & 3.9 & 11.8 & 7.8 & 4.8 \\
\hline \multirow[t]{4}{*}{ Marital status } & Single & 51.4 & 52.9 & 29.4 & 37.1 \\
\hline & Married & 44.2 & 31.4 & 62.1 & 53.2 \\
\hline & Separated & 4.4 & 5.9 & 5.2 & 3.2 \\
\hline & Widowed & 0.0 & 9.8 & 3.3 & 6.5 \\
\hline \multirow{5}{*}{ Educational level } & Primary & 12.2 & 15.7 & 1.3 & 8.1 \\
\hline & Secondary/Technical & 64.6 & 39.2 & 15.7 & 37.1 \\
\hline & Higher (incomplete) & 13.3 & 11.8 & 13.7 & 21.0 \\
\hline & Higher (completed) & 9.9 & 27.5 & 45.8 & 24.2 \\
\hline & Post-graduate & 0.0 & 3.9 & 23.5 & 8.1 \\
\hline \multirow[t]{6}{*}{ Household income ( $\left.\mathrm{MW}^{1}\right)$} & Up to $1 \mathrm{MW}$ & 11.0 & 9.8 & 0.7 & 11.3 \\
\hline & 1 to $2 \mathrm{MW}$ & 34.3 & 21.6 & 5.9 & 9.7 \\
\hline & 3 to $4 \mathrm{MW}$ & 36.5 & 19.6 & 15.0 & 32.3 \\
\hline & 5 to $10 \mathrm{MW}$ & 16.6 & 35.3 & 37.9 & 27.4 \\
\hline & 11 to $20 \mathrm{MW}$ & 1.7 & 11.8 & 30.7 & 16.1 \\
\hline & Above $20 \mathrm{MW}$ & 0.0 & 2.0 & 9.8 & 3.2 \\
\hline
\end{tabular}

I - young and interested; II - mixed and indifferent; III - graduates and successful; IV- healthy women.

${ }^{1} \mathrm{MW}$ - Brazilian minimum national wage during the study was BRL 678.00 in 2013. 
products (Karabasanavar et al., 2011; Mane et al., 2012; Sakaridis et al., 2013).

Group II may be classified as Mixed and indifferent, and is the smallest segment identified in this study, with 51 people (11\% of the sample). It is a heterogeneous group, with large numbers of single people of various ages, educational levels varying between secondary/technical and higher education and household incomes between one and ten times the minimum wage.

Despite knowing the benefits of buffalo meat, this group believes that it should be more affordable (cheaper) than beef (56.9\%) (Table 4). They are not willing to pay extra for buffalo meat with a certified origin. According to Insch and Jackson (2014), some consumers do not buy what they want for economic reasons. Among the analysed clusters, this group consumes the least buffalo meat (13.7\%) and is less predisposed to include this food in meals more often than other groups.
The potential consumers $(86.3 \%)$ in this group, in addition to citing the unavailability of the product at points of sale and their ignorance of its benefits, also considered buffalo meat to be tough and have a distinctive buffalo flavour (that differs from beef). This group was the least likely to include buffalo meat in meals relative to the other groups. Insch and Jackson (2014) and Miljkovic and Effertz (2010) report that consumers are influenced by factors involving food characteristics, but the context in which they operate or the society to which they belong can also influence their purchase decisions.

Group III, Graduates and successful, is the secondlargest group, with 153 people (34\% of the sample), most of whom are married and between the ages of 35 and 55. This segment includes people who are very willing to include buffalo meat in their meals. They have high educational levels and household income corresponding to five to twenty times the minimum wage. Consumers of buffalo

Table 4 - Profile of interviewed consumers and potential consumers (\%)

\begin{tabular}{|c|c|c|c|c|c|}
\hline \multirow{2}{*}{ Variable } & & \multicolumn{4}{|c|}{ Cluster } \\
\hline & & $\mathrm{I}(\mathrm{n}=181)$ & $\mathrm{II}(\mathrm{n}=51)$ & III $(\mathrm{n}=153)$ & $\operatorname{IV}(\mathrm{n}=62)$ \\
\hline Have heard of buffalo meat & Yes & 89.0 & 90.2 & 93.5 & 90.3 \\
\hline $\begin{array}{l}\text { What is most important for consumers } \\
\text { at the time of purchase? }\end{array}$ & $\begin{array}{l}\text { Origin of meat } \\
\text { Brand } \\
\text { Nutritional value } \\
\text { Price } \\
\text { Colour of meat and fat } \\
\text { Packaging }\end{array}$ & $\begin{array}{c}40.3 \\
8.3 \\
50.3 \\
31.5 \\
2.8 \\
3.9\end{array}$ & $\begin{array}{c}33.3 \\
13.7 \\
19.6 \\
29.4 \\
27.5 \\
7.8\end{array}$ & $\begin{array}{c}47.1 \\
7.2 \\
62.1 \\
30.1 \\
15.0 \\
8.5\end{array}$ & $\begin{array}{c}35.5 \\
6.5 \\
9.7 \\
29.0 \\
100.0 \\
6.5\end{array}$ \\
\hline $\begin{array}{l}\text { Would you pay more for buffalo meat } \\
\text { with a certified origin? }\end{array}$ & Yes & 100.0 & 23.5 & 98.7 & 100.0 \\
\hline $\begin{array}{l}\text { Compared the price of beef, buffalo } \\
\text { meat should be: }\end{array}$ & $\begin{array}{l}\text { Cheaper } \\
\text { Same price } \\
\text { More expensive }\end{array}$ & $\begin{array}{l}38.1 \\
50.8 \\
11.0\end{array}$ & $\begin{array}{c}56.9 \\
33.3 \\
9.8\end{array}$ & $\begin{array}{l}35.3 \\
49.7 \\
15.0\end{array}$ & $\begin{array}{c}38.7 \\
56.5 \\
4.8\end{array}$ \\
\hline $\begin{array}{l}\text { Do you think it is important for buffalo } \\
\text { meat to have the SIF seal? }\end{array}$ & Yes & 100.0 & 76.5 & 100.0 & 100.0 \\
\hline $\begin{array}{l}\text { Where would you prefer to buy } \\
\text { buffalo meat? }\end{array}$ & $\begin{array}{l}\text { Direct from the producer } \\
\text { Specialised supplier } \\
\text { Open-air market } \\
\text { Supermarket } \\
\text { Other }\end{array}$ & $\begin{array}{c}7.7 \\
35.9 \\
17.7 \\
86.2 \\
0.6\end{array}$ & $\begin{array}{c}11.8 \\
33.3 \\
13.7 \\
76.5 \\
0.0\end{array}$ & $\begin{array}{c}8.5 \\
41.8 \\
13.1 \\
88.2 \\
0.0\end{array}$ & $\begin{array}{c}3.2 \\
46.8 \\
14.5 \\
85.5 \\
1.6\end{array}$ \\
\hline $\begin{array}{l}\text { Having access to information regarding } \\
\text { buffalo meat could improve your odds } \\
\text { of purchasing the product. }\end{array}$ & Yes & 100.0 & 82.4 & 100.0 & 100.0 \\
\hline & & $\mathrm{I}(\mathrm{n}=152)$ & $\mathrm{II}(\mathrm{n}=32)$ & III $(n=103)$ & $\mathrm{IV}(\mathrm{n}=47)$ \\
\hline $\begin{array}{l}\text { Do you know the benefits of buffalo } \\
\text { meat? }\end{array}$ & Yes & 16.0 & 37.3 & 32.7 & 24.2 \\
\hline Most cited benefits & $\begin{array}{l}\text { Less fat } \\
\text { Description lacking details } \\
\text { No reply } \\
\text { Stronger } \\
\text { Healthy } \\
\text { More tender } \\
\text { More protein }\end{array}$ & $\begin{array}{c}41.4 \\
3.4 \\
10.3 \\
6.9 \\
13.8 \\
3.4 \\
20.7\end{array}$ & $\begin{array}{c}42.1 \\
10.5 \\
21.1 \\
10.5 \\
10.5 \\
5.3 \\
0.0\end{array}$ & $\begin{array}{c}62.0 \\
6.0 \\
4.0 \\
4.0 \\
12.0 \\
8.0 \\
4.0\end{array}$ & $\begin{array}{c}50.0 \\
14.3 \\
0.0 \\
0.0 \\
21.4 \\
0.0 \\
14.3\end{array}$ \\
\hline
\end{tabular}

I - young and interested; II - mixed and indifferent; III - graduates and successful; IV- healthy women; SIF - Brazilian Federal Inspection Service. 
Table 5 - Profile of interviewees who consume buffalo meat (\%)

\begin{tabular}{|c|c|c|c|c|c|}
\hline \multirow{2}{*}{ Variable } & & \multicolumn{4}{|c|}{ Cluster } \\
\hline & & $\mathrm{I}(\mathrm{n}=26)$ & II $(\mathrm{n}=7)$ & III $(n=33)$ & IV $(n=17)$ \\
\hline Consume buffalo meat & Yes & 14.4 & 13.7 & 21.6 & 27.4 \\
\hline \multirow[t]{5}{*}{ How many times per month? } & Daily & 15.4 & 28.6 & 3.0 & 11.8 \\
\hline & Weekly & 26.9 & 28.6 & 48.5 & 5.9 \\
\hline & Biweekly & 3.8 & 14.3 & 3.0 & 5.9 \\
\hline & Monthly & 23.1 & 14.3 & 24.2 & 47.1 \\
\hline & Annually & 30.8 & 14.3 & 21.2 & 29.4 \\
\hline \multirow{5}{*}{$\begin{array}{l}\text { Your habit of eating buffalo } \\
\text { meat comes from: }\end{array}$} & Family & 46.2 & 42.9 & 30.3 & 29.4 \\
\hline & Availability in restaurants & 7.7 & 14.3 & 27.3 & 23.5 \\
\hline & Relationship with family/friends who eat it & 38.5 & 14.3 & 9.1 & 17.6 \\
\hline & Information from newspapers, magazines and $\mathrm{TV}$ & 3.8 & 28.6 & 24.2 & 17.6 \\
\hline & Information from cooking lessons & 3.8 & 0.0 & 9.1 & 11.8 \\
\hline \multirow[t]{3}{*}{ You usually eat buffalo meat: } & At your home & 69.2 & 71.4 & 78.8 & 58.8 \\
\hline & At homes of family or friends & 26.9 & 14.3 & 6.1 & 23.5 \\
\hline & In restaurants & 3.8 & 14.3 & 15.2 & 17.6 \\
\hline $\begin{array}{l}\text { Consume buffalo meat and } \\
\text { would include it in the diet } \\
\text { more often }\end{array}$ & Yes & 96.2 & 66.7 & 90.3 & 87.5 \\
\hline
\end{tabular}

I - young and interested; II - mixed and indifferent; III - graduates and successful; IV- healthy women.

Table 6 - Reasons and justifications provided by interviewees who do not consume buffalo meat (\%)

\begin{tabular}{|c|c|c|c|c|c|}
\hline \multirow{2}{*}{ Variable } & & \multicolumn{4}{|c|}{ Cluster } \\
\hline & & $\mathrm{I}(\mathrm{n}=153)$ & $\mathrm{II}(\mathrm{n}=44)$ & III $(n=122)$ & $\operatorname{IV}(\mathrm{n}=45)$ \\
\hline \multirow{8}{*}{$\begin{array}{l}\text { Reasons for not eating } \\
\text { buffalo meat }{ }^{1}\end{array}$} & Characteristic flavour (buffalo) & 1.3 & 9.1 & 1.6 & 0.0 \\
\hline & Considered a tough meat & 2.6 & 11.4 & 2.5 & 4.4 \\
\hline & Not available at points of sale & 48.4 & 34.1 & 67.2 & 48.9 \\
\hline & Benefits of buffalo meat unknown & 46.4 & 34.1 & 43.4 & 44.4 \\
\hline & Related to the production system (dirty system with mud) & 2.6 & 2.3 & 2.5 & 0.0 \\
\hline & No specific reason & 16.3 & 18.2 & 9.0 & 20.0 \\
\hline & Do not consume, but would include buffalo meat in meals & 97.3 & 74.4 & 95.7 & 97.8 \\
\hline & & $\mathrm{I}(\mathrm{n}=4)$ & $\mathrm{II}(\mathrm{n}=11)$ & III $(n=5)$ & $\operatorname{IV}(\mathrm{n}=1)$ \\
\hline \multirow{7}{*}{$\begin{array}{l}\text { Reasons for not including } \\
\text { buffalo meat in meals }{ }^{1}\end{array}$} & Benefits of buffalo meat unknown & 25.0 & 36.4 & 60.0 & 0.0 \\
\hline & Never eaten before & 50.0 & 27.3 & 0.0 & 0.0 \\
\hline & Different flavour & 0.0 & 27.3 & 0.0 & 0.0 \\
\hline & Allergy & 25.0 & 0.0 & 0.0 & 0.0 \\
\hline & Dark colour & 0.0 & 9.1 & 0.0 & 0.0 \\
\hline & Tough meat & 0.0 & 0.0 & 40.0 & 0.0 \\
\hline & Bad smell & 0.0 & 0.0 & 0.0 & 100.0 \\
\hline
\end{tabular}

I - young and interested; II - mixed and indifferent; III - graduates and successful; IV- healthy women.

${ }^{1}$ Here the interviewee was free to choose one or more alternatives.

Table 7 - Sensory analysis outcomes with respect to the sample most liked by the consumer and purchase intention for the product (\%)

\begin{tabular}{|c|c|c|c|c|c|}
\hline \multirow{2}{*}{ Assessment of the attribute } & & \multicolumn{4}{|c|}{ Cluster } \\
\hline & & $\mathrm{I}(\mathrm{n}=181)$ & $\mathrm{II}(\mathrm{n}=51)$ & III $(\mathrm{n}=153)$ & $\mathrm{IV}(\mathrm{n}=62)$ \\
\hline \multirow{2}{*}{$\begin{array}{l}\text { Which sample was liked most by } \\
\text { the consumer }\end{array}$} & 254 (buffalo) & 70.7 & 58.8 & 60.8 & 56.5 \\
\hline & 682 (beef) & 29.3 & 41.2 & 39.2 & 43.5 \\
\hline \multirow[t]{5}{*}{ Intention to purchase buffalo meat } & Would certainly buy & 68.0 & 54.9 & 56.2 & 51.6 \\
\hline & Would possibly buy & 21.0 & 25.5 & 22.9 & 30.6 \\
\hline & May or may not buy & 8.3 & 11.8 & 11.8 & 14.5 \\
\hline & Possibly would not buy & 1.1 & 3.9 & 2.6 & 1.6 \\
\hline & Certainly would not buy the product & 1.7 & 3.9 & 6.5 & 1.6 \\
\hline \multirow[t]{5}{*}{ Intention to purchase beef } & Would certainly buy & 41.4 & 41.2 & 45.1 & 53.2 \\
\hline & Would possibly buy & 31.5 & 35.3 & 33.3 & 24.2 \\
\hline & May or may not buy & 16.6 & 17.6 & 11.1 & 12.9 \\
\hline & Possibly would not buy & 2.8 & 2.0 & 5.2 & 3.2 \\
\hline & Certainly would not buy the product & 7.7 & 3.9 & 5.2 & 6.5 \\
\hline
\end{tabular}

I - young and interested; II - mixed and indifferent; III - graduates and successful; IV- healthy women. 
meat represent $21.6 \%$ of this group; their consumption habits are mostly based on family and restaurants; and they consume buffalo meat every week but are also willing to include it more often in meals. Among potential consumers (78.4\%), failure to consume buffalo meat was explained by the unavailability of the product at points of sale and a lack of information regarding its benefits. These potential consumers feel that buffalo meat should be more expensive than beef, and this feature is considered favourable and may be related to their higher incomes. This type of income/ consumption relationship for meat is one of the factors with the highest impact on the acquisition and acceptance of foods, especially with respect to price and type of preferred meat. Some consumers seek more affordable products, while others associate price with quality, considering the most expensive products to have the best quality, or vice versa. This type of conflict can be solved through market segmentation (Bernués et al., 2012; Onwezen et al., 2012; Insch and Jackson, 2014).

Group IV, Healthy women, consists of 62 people (14\% of the sample); they are mostly between the ages of 25 and 45, are married, and have secondary to higher levels of education and household incomes that are three to ten times the minimum wage. They stand out because they know about the benefits of buffalo meat, i.e., that it is healthier and has a lower fat content. In the sensorial test, $56.5 \%$ of participants in this group opted for buffalo meat, a lower proportion compared with other groups. However, most stated that they were willing to buy it. In this group, $100 \%$ consider the colour of meat and fat at the time of purchase and are willing to pay extra for buffalo meat with a certified origin.

This group has the highest number of buffalo meat consumers compared with the other groups (27.4\%); however, their consumption frequency is low (monthly and annually). Their consumption habits are based on the family and restaurants. This group also consumes less meat at home, choosing to consume this type of food especially at houses of friends and restaurants. Potential consumers (72.6\%) stated that they did not consume buffalo meat because of its unavailability in the market and their lack of knowledge regarding its benefits; however, they were the most interested in including buffalo meat in their diets. According to Vieira et al. (2010) and Carvalho and Alves (2012), in recent decades, significant changes in the compositions and sizes of families have changed gender relations, making women important consumers who are also demanding with regard to the nutritional quality of food, especially meat.

Verbeke and Ward (2006) report that women tend to place more importance on and pay greater attention to specific indicators of food quality. According to Banovic et al. (2009), women are receptive to new products, tastings, and special offers, with the family being the main reason for their purchase of food. Siró et al. (2008) described the profile of the contemporary woman as someone who is constantly looking for new products and takes very special care of her physical and mental health, thus seeking healthy foods.

Regarding purchase intention during the sensory analysis, among the four studied clusters, it was observed that most people opted for buffalo meat and stated that they would certainly buy it (Table 7).

This finding shows that beef can be replaced by buffalo without affecting organoleptic characteristics. These indications are important both for the market, which can increase the value of buffalo meat (currently sold at $20 \%$ below the price of beef), and for the consumer, who can consume a healthier meat without losing sensory characteristics.

\section{Conclusions}

Consumers show a greater acceptance of buffalo meat based on the characteristics of flavour, colour, succulence, and tenderness. The study helps to identify market segments with distinct features that, combined with a targeted marketing strategy, can be used to leverage the supply chain.

\section{Acknowledgments}

The authors thank Pró-Reitoria de Pesquisa e PósGraduação (PROPESP) and Fundação de Amparo e Desenvolvimento da Pesquisa (FADESP).

\section{References}

Banovic, M.; Fontes, M. A. and Grunert, K. G. 2012. Impact of product familiarity on beef quality perception. Agribusiness 28:157-172. doi: 10.1002/agr.21290.

Banovic, M.; Grunert, K. G.; Barreira, M. M. and Fontes, M. A. 2009. Beef quality perception at the point of purchase: A study from Portugal. Food Quality and Preference, 20:335-342. doi: 10.1016/ j.foodqual.2009.02.009.

Bernardes, O. 2007. Bubalinocultura no Brasil: situação e importância econômica. Revista Brasileira de Reprodução Animal 31:293-298.

Bernués, A.; Ripoll, G. and Panea, B. 2012. Consumer segmentation based on convenience orientation and attitudes towards quality attributes of lamb meat. Food Quality and Preference 26:211-220. doi: 10.1016/j.foodqual.2012.04.008.

Behrens, J. H.; Barcellos, M. N.; Frewer, L. J.; Nunes, T. P.; Franco, B. D. G. M.; Destro, M. T. and Landgraf, M. 2010. Consumer purchase habits and views on food safety: A Brazilian study. Food Control 21:963-969. doi: 10.1016/j.foodcont.2009.07.018. 
Brandão, F. S.; Ceolin, A. C.; Canozzi, M. E. A.; Révillion, J. P. P. and Barcellos J. O. J. 2012. Confiança e agregação de valor em carnes com indicação geográfica. Arquivo Brasileiro de Medicina Veterinária e Zootecnia 64:458-464. http://dx.doi.org/10.1590/ S0102-09352012000200028

Brisola, M. V. and Castro A. M. G. 2005. Preferências do consumidor de carne bovina no Distrito Federal pelo ponto de compra e pelo produto adquirido. Caderno de Pesquisas em Administração 12:81-99.

Carvalho, A. A. and Alves, J. E. D. 2012. Explorando o consumo das famílias brasileiras e sua interface com o ciclo de vida e gênero. Revista Brasileira de Economia Doméstica 23:6-29.

Giordano, G.; Guarini, P.; Ferrar, P.; Biondi-Zoccai, G.; Schiavone, B. I. P. and Giordano, A. 2010. Beneficial impact on cardiovascular risk profile of water buffalo meat consumption. European Journal of Clinical Nutrition 64:1000-1006. doi: 10.1038/ejen.2010.108.

Hair Jr., J. F.; Babin, B.; Money, A. H.; Samouel, P. 2007. Fundamentos de métodos de pesquisa em administração. Bookman, Porto Alegre.

Hill, M. M. and Hill, A. 2012. Investigação por questionário. Edições Silabo, Lisboa.

Iannario, M.; Manisera, M.; Piccolo, D. and Zuccolotto, P. 2012. Sensory analysis in the food industry as a tool for marketing decisions. Advances in Data Analysis and Classification 6:303-321. doi: 10.1007/s11634-012-0120-4.

Insch, A. and Jackson, E. 2014. Consumer understanding and use of country-of-origin in food choice. British Food Journal 116:62-79. http://dx.doi.org/10.1108/BFJ-10-2011-0275

Jo, Y. J.; Jang, M. Y.; Jung, Y. K.; Kim, J. H.; Sim, J. B; Chun, J. Y.; Yoo, S. M.; Han, G. J.; and Min, S. G. 2014. Effect of novel quick freezing techniques combined with different thawing processes on beef quality. Korean Journal for Food Science of Animal Resources. 34:777-783. http://dx.doi.org/10.13050/foodengprog.2015.19.3.243

Johnson, R. A. and Wichern, D. W. 2007. Applied multivariate statistical analysis. Upper Saddle River, NJ: Pearson. doi: 10.1007/ 978-3-540-72244-1.

Karabasanavar, N. S.; Singha S. P.; Umapathi V.; Kumarc, D.; Patil, G. and Shebannavare, S. N. 2011. A highly specific PCR assay for identification of raw and heat treated mutton (Ovis aries). Small Ruminant Research 100:153-158. doi: 10.1016/j.smallrumres.201 1.07.009.

Lee, S. Y.; Kim, K. L; Hwang, I. G.; Yu, S. M.; Min, S. G.; and Choi, M. J. 2015. Quality characteristics of frozen beef developed into home meal replacement products under various storage conditions. Food Engineering Progress 19:243-249. http://dx.doi. org/10.13050/foodengprog.2015.19.3.243

Lira, G. M.; Mancini-Filho, J.; Torres, R. P.; Oliveira, A. C.; Vasconcelos, A. M. A.; Omena, C. M. B. and Almeida, M. C. S. 2005. Composição centesimal, valor calórico, teor de colesterol e perfil de ácidos graxos da carne de búfalo (Bubalis bubalis) da cidade de São Luiz do Quitunde-AL. Revista Instituto Adolfo Lutz 64:31-38.

Malhotra, N. 2012. Pesquisa de marketing uma orientação aplicada. Bookman, Porto Alegre.

Mane, B. G.; Mendiratta, S. K.; Tiwari, A. K. and Bhilegaokar, K. N. 2012. Detection of adulteration of meat and meat products with buffalo meat employing polymerase chain reaction assay in food analytical methods. Food Analytical Methods 5:296-300. doi: 10.1007/s12161-011-9237-x

McGloin, A.; Delaney, L.; Hudson, E. and Wall, P. 2009. Nutrition communication: The challenge of effective food risk communication. Proceedings of the Nutrition Society 68:135-141. doi: $10.1017 / \mathrm{S} 0029665109001153$.

Miljkovic, D. and Effertz, C. 2010. Consumer behavior in food consumption: Reference price approach. British Food Journal 112:32-43. http://dx.doi.org/10.1108/00070701011011182

Minin, V. P. R. 2012. Análise sensorial: Estudos com consumidores. Editora UFV, Viçosa, MG.

Onwezen, M. C.; Reinders, M. J.; Van der Lans, I. A.; Sijtsema, S. J.; Jasiulewicz, A.; Guardia, M. D. and Guerrero, L. A. 2012. Crossnational consumer segmentation based on food benefits: The link with consumption situations and food perceptions. Food Quality and Preference 24:276-286. doi: 10.1016/j.foodqual.2011.11.002.

Pinheiro, F. A.; Cardoso, W. S.; Chaves, K. F.; Oliveira, A. S. B. and Rios S. A. 2011. Perfil de consumidores em relação à qualidade de alimentos e hábitos de compras. Revista Unopar Cientifica Ciências Biológicas e da Saúde 13:95-102.

Rutsaert, P.; Barnett, J.; Gaspar, R.; Marcu, A.; Pieniak, Z.; Seibt, B. and Verbeke, W. 2005. Beyond information seeking: Consumers' online deliberation about the risks and benefits of red meat. Food Quality and Preference 39:191-201. doi: 10.1016/j.foodqual.2014.07.011

Sakaridis, I.; Ganopoulos, I.; Argiriou, A. and Tsaftaris, A. 2013. A fast and accurate method for controlling the correct labeling of products containing buffalo meat using high resolution melting (HRM) analysis. Meat Science 94:84-88. doi: 10.1016/ j.meatsci.2012.12.017.

Schnettler, B.; Vidal, R.; Silva, R.; Vallejos, L. and Sepúlveda, N. 2009. Consumer willingness to pay for beef meat in a developing country: The effect of information regarding country of origin, price and animal handling prior to slaughter. Food Quality and Preference 20:156-165. doi: 10.1016/j.foodqual.2008.07.006

Silva, S. L. and Nardi Junior, G. 2014. Produção de derivados bubalinos e mercado consumidor. Tekhne e Logos 5:15-30.

Siró, I.; Kápolna, E.; Kápolna, B. and Lugasi, A. 2008. Functional food. Product development, marketing and consumer acceptance A review. Appetite 51:456-467. doi: 10.1016/j.appet.2008.05.060.

Trienekens, J. H.; Wognuma, P. M.; Beulens, A. J. M. and Van der Vorst, J. G. A. J. 2012. Transparency in complex dynamic food supply chains. Advanced Engineering Informatics 26:55-65. doi: 10.1016/j.aei.2011.07.007.

Verbeke, W.; Perez-Cueto, F. J. A.; Barcellos, M. D.; Krystallis, A. and Grunert, K. G. 2010. European citizen and consumer attitudes and preferences regarding beef and pork. Meat Science 84:284-292. doi: 10.1016/j.meatsci.2009.05.001.

Verbeke, W. and Ward, R. W. 2006. Consumer interest in information cues denoting quality, traceability and origin: An application of ordered probit models to beef labels. Food Quality and Preference 17:453-467. doi:10.1016/j.foodqual.2005.05.010.

Vieira, A. C. P.; Buianain, A. M. and Spers, E. E. 2010. A segurança do alimento e a necessidade da informação aos consumidores. Cadernos de Direito 10: 21-37. http://dx.doi.org/10.15600/22381228/cd.v10n19p21-37 